\title{
Evaluating Gender Based Behavior in Historical Urban Public Place \\ Case study: Grand Bazaar, Kerman, Iran \\ ${ }^{*}$ Ph. D Candidate. AIDA JALALKAMALI 1 (D, MA. ELHAM ANJOMSHOA 2 (D) \\ 1 Faculty of Architecture, Eastern Mediterranean University, Famagusta, Cyprus \\ 2 Faculty of Architecture, Yazd University, Yazd, Iran

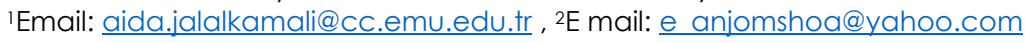

\begin{tabular}{|l|}
\hline A R T I C L E I N F O: \\
\hline Article history: \\
Received 16 Marchl 2018 \\
Accepted 30 May 2018 \\
Available online 28 July 2018 \\
\hline Keywords: \\
Public Place; \\
Spatial Behaviour; \\
Fear of Crime; \\
Environmental \\
Psychology; \\
Public Place \\
Functionality.
\end{tabular}

This work is licensed under a Creative Commons Attribution - NonCommercial - NoDerivs 4.0. "CC-BY-NC-ND"

\begin{abstract}
A B S T R A C T
The study evaluates the spatial behaviors of women in urban public place through 'fear of crime' and 'public place functionality' factors; by using direct observations and questionnaire within the Grand Bazaar as a historical urban public place in the center of Kerman, which is located in the Southwest part of Iran. The study provides a particular perspective to the analysis and understanding of how women make decisions and behave in a spatial setting based on environmental psychology studies. This study applies combinational research methods including qualitative and quantitative approach, including analytical, descriptive, correlation, and logical reasoning methods. This study also conducts direct observation in order to search the strengths and weaknesses of Grand Bazaar as a public place. The results of the study reveal that there is a significant correlation between fear of crime and women's environmental perception of Grand Bazaar. Furthermore, the research findings indicate that the anxiety of being in less crowded parts of Bazaar is more tangible among women than men. On the other hand, the results show there is a significant correlation between time periods and women's activities in Grand Bazaar.
\end{abstract}

JOURNAL OF CONTEMPORARY URBAN AFFAIRS (2019), 3(1), 143-153. https://doi.org/10.25034/ijcua.2018.4691

Www.ijcua.com

Copyright (C) 2018 Journal Of Contemporary Urban Affairs. All rights reserved.

\section{Introduction}

Altman \& Zube in (1989) refer to the three critical human dimensions that every public space should provide; "the user's spatial rights", "their essential needs" and the meanings they seek. Regarding the equal spatial rights and fulfilling user's needs, Franck \& Paxson (1989) mentioned that with considering the women presence and usages of public spaces, there are visible discriminations on women's rights and their satisfaction within public spaces. On the other side looking to the spatial behavior patterns of human, it shows that women behaviors in public spaces are affected by very deeply rooted psychological, social, and cultural environmental factors, which are created and nourished by societies. Although, the recent consideration of gender issues in designing new public spaces and places increased, and more women are using them frequently and freely, but still in some

*Corresponding Author:

Faculty of Architecture, Eastern Mediterranean University, Famagusta, Cyprus

E-mail address: aida.jalalkamali@cc.emu.edu.tr 
cases it seems there is an obvious difference between men and women spatial behavior in public spaces; and it requires more detailed investigation in order to conduct gender-based behaviors. Furthermore, systematic observations, applying questionnaires in case study indicate that there is a significant difference between women and men spatial behavior within the historic urban public place of Grand Bazaar in Kerman province.

\section{Public Places and Spatial Behaviors}

According to (Carr, Francis, Rivlin, \& Stone, 1992) public spaces and places offering "an image of accessible urban, suburban, rural, and wilderness landscapes. The term "public" connotes the idea that these settings are accessible to everyone-people of a community, state, or nation, regardless of age, gender, ethnicity, physical handicap, or other characteristics." Public spaces can stay as a common ground, a place where people can build their communities by carrying out their functional and ritual activities. These activities can take place as daily routines or in periodic festivals. Public spaces are also hosting more "private" activities as well; such as selling and buying things, exercising, gardening, or simply finding a place to exist. (Altman \& Zube, 1989) The notion of public spaces is based on "daily interactions and activities" between people, and physical structure of public spaces. However, these activities and usages can be restricted by economic, social, cultural, and other constraints. Each one of these factors is defined as "hidden" structures of public spaces; therefore, there is a need to examine and elaborate them as a contextual dimension of behavior. (Golledge \& Stimson, 1997).

furthermore, each public place should be defined according to first, which type of behavior is associated with or it may happen on that place, second how the physical parameters of that place are organized, and third "the descriptions, or conception which people hold of that behavior in that physical environment." (Canter, 1977) In this vain Dovey (1985) also specified that space holds ideas of "the interaction between people and a physical setting together with a set of meanings that both emerge from and inform this experience and interaction. (p. 94)"

Public place by definition is part of "public realm"; and public realm itself is considered as a set of behavior settings (Lang, 1987). According to behavior settings, public places consisting of a recurring (or standing) behavior pattern, a milieu (pattern of built form) and a time period. This "milieu" has the affordances to let the behaviors to occur. Each and every public place have their own patterns of behavior settings, it means that what will happen in each place depends on motivations, predispositions, competencies and knowledge of people involved. Therefore, the same set of build form (environment) may produce different behavioral patterns due to different users, different times of a day, week, or a year; also may some of them be occurring often time on a daily basis or even throughout the day or year, while others may occur only on special occasions (Lang J., 2007).

Generally, in order to examine human environmental settings, there is a need to consider all applicable variables and their functional relationships. These variables can consist of the physical and the built aspects of the environment, culture, social, and political systems of societies; also the other variable which is affecting spatial behavior is, "environmental psychology", this factor intervening and affecting the process, a human perceives the environment and acts within it.

However, these variables and process of their effectiveness are varied in each case due to different types of users in place. Therefore, it is necessary to narrow down the type of users and the context that these interactions take place. The study concern to focus on what are the hidden parameters that are defining and coding women's certain behavioral settings in public spaces, in an Islamic historical context. In this manner, Franck \& Paxson (1989) refer to the importance of understanding the context within which women do (or do not) use public spaces. Many of these contexts, do restrict women activities and do confine potentially positive aspects of their experiences. Women can use and enjoy public spaces alone without being accompanied by men, only if they overcome different obstacles and following specific restrictions. Men also may have some limitations, but this situation is different for women as it is more concern about fear of crime, in particular places and times. Still, women don't have the same "freedom of street" as men have significantly. In order to increase that freedom, it is required to understand and specify the ways in which women are restricted and the reasons behind them.

For the most parts of the world, girls (then women) have been raised in a different manner, they have been expected to act differently, to have different responsibilities, and 
hold different attitudes than boys and (then men) in their societies. These and the other reasons cause women and men gain different attitudes, actions, and experiences toward build environments. Although knowing precisely what these differences are, they vary culturally and historically, also according to class, age, and many other environmental conditions but, the existence of powerful gender differences is universal. In order to understand any built environment, it is important to recognize how these gender differences perceive the space, how much they have enacted the space, and how they create different needs in the built environment. The first priority of any improvement in women's lives is to examine the existence gender difference's assumptions and see whether they show the women and men's everyday lives and whether the built environments do meet women's needs. (Franck K. A., 2002).

\section{Identifying Gender Differences and Women's Needs}

Looking closely to the key differences between men and women, it shows men and women through their lives gain different spatial behavior in built environments. The major motives behind these differences come through first, a different process of socialization they have, second, their male and female selfidentity development, and third through the labor division process. As Franck \& Paxson (1989) stated how girls from an early age have been encouraged to be more physically active, to be less exploratory and more fearful than boys. On the other study, Susan Saegert and Roger Hart (1978) shows that in United States the range of girls' spatial activities beyond the home is smaller than boys' spatial activities, and girls' play is less tending to manipulate the environment. Girls also being taught to occupy less space and cross their legs (Henley, 1977). Iris Marion Young discuss that generally women control their behavior in their bodily occupation of space, keeping their arms and legs closer to their body when they are moving. Also to put less effort and less movement in their engagement with activities which require lifting, pulling, pushing, or throwing. "Feminine existence appears to posit an existential enclosure between herself and the space surrounding her, in such a way that the space that belongs to her and is available to her grasp and manipulation is constricted and space beyond is not available to her movement" (Young, 1990, p. 151). It is important to specify that, in a lifetime these apparently come "rules" are applying to the behavior of adult women in their use of public spaces.

From a wider perspective, women's restricted movement and their constriction mobility, outside a home in public spaces do not just belong to western industrialized countries, but also in some other societies. Fenster (1999) and Moser (1984) noted, that This issue even is harsher in Muslim countries where they are expected to cover themselves with vail and limit their travels outside the local neighborhood unless to have a male accompany.

The kind of actions women and men value is also related to their self-identity as men and women. Male self-identity is defined to have a tendency to disregard domestic sphere and everyday life, and instead to give value to the abstraction, business, and the public world. Nancy Hartsock (1983) argues that men see the world in two dualism oppositions - abstract/ concrete, culture/ nature, mind/ body, wherein each one of the pairs, the first member refers to the male and the second one to the female. In opposite sphere, female self-identity is defined within the context of home and family and embrace everyday life with a wide range of domestic connections and continuities (Hartsick, 1983).

\section{1. "Domestic" and "Public" Realm}

Gender differences have got interesting terminologies of "domestic" and "public" realm in the field of 'environmental psychology'. Accordingly, women have been defined as domestic part of the society where they have been located at the house and being separated from the rest of the society, while men have been considering as public sphere of society where they have more chance to be integrated with the public realm of the city. Referring to Franck K. A. (2002)"The social and spatial organization of these two realms, the activities pursued, the meanings they have, and the degree to which women's movements are restricted all differ culturally and historically", But the willing of having divided sexual environment in two asymmetrical realms of the domestic and public is not specified for certain regions on the world. It seems, this tendency has been rooted throughout the history and continues today all around the world in different forms, form many Muslim countries, to Greek villages (Hirschon, 1981), to U.S. cities and suburbs (Franck \& Paxson, 1989), and to Bedouin settlements in Israel (Fenster, 1999). This division prevents women to be 
present fully in the society in their high performance and their mobility in public spaces. (Franck K. A., 2002) it is also possible to say, public spaces have been planned and designed by men's public realm, therefore public spaces despite of evident present of women couldn't fully address the needs of women ( (Franck K. A., 2002).

The specific roles have been specified for women in societies are developed and strengthened by gender base division of labor in past and present. However, women accept the responsibility for house care, child care, and elder care. In a study that William Michelson (1985) conduct on employed women and their families in Toronto, he realized, that when all the duties of being an employed woman, taking the house care, child care, commuting, and shopping together; women become a full-time worker, without any "off work" who is spending 11 hours per day around her domestic responsibilities. She will have very restricted free times for herself and her individual activities. However, this issue also affects their usage of public spaces and places; ether they spent less time compare to the men in public spaces for leisure activities, or their most activities in public spaces will be specified to meet the needs of house like grocery shopping or taking their children to play or shop for them and so on. In a same line. Wilson (1991) state: "since women's 'proper' place has historically been in or near home, they generally not been welcome in public space as men, particularly when their reason for being there is not related to their homemaker role".

\subsection{Fear of crime and Vulnerability}

The other critical assumption in majority of studies which focused on women's usage of public spaces is "fear of crime and vulnerability" in physical environment. The studies show women's spatial behavior in public spaces are highly related to their perceptions of safety on that space. It is well defined in the sociology and criminology literatures of gender studies, that women adopt more fear of crime, and this is mostly related to their sense of physical vulnerability to men, especially to raping and sexual murder ( (Baumer, 1978); Waar 1985; and Gordon et al. 1980). On the other studies which were conducted in United State and Canada, they reveal, women have significantly more fear of crime than men (Office of Solicitor General of Canada, 1985; Riger \& Gordon, (1981)l however in the real-life women are less frequently victimized of crime (except of sexual assault) than are men. The perception of male violence in certain contexts, cause great effect on many women's use of space, in this way women accept two kinds of precautions to defense against probable dangerous situations: isolation or avoiding situations perceived as unsafe, and "street savvy" as judging carefully, and where to sit on a bus ((Altman \& Zube, 1989); (Valentine, 1989)). Altogether the factor of 'fear of crime and vulnerability' and in its consequence the precautionary behaviors cause women to restrict when, where, and how they move in public space ( (Franck \& Paxson, 1989); (Day, 1995), (Day, 2000)).

\section{Study Framework}

This study has shown earlier that how psychological variables are intervening between women and built environment; and their importance in expanding the behavioral outcomes of these interactions in public spaces. Conducting the spatial behavioral patterns of women in an old commercial public place (Grand Bazaar), is the main goal of this research. Among all those factors which were discussed in the literature review, this study tries to draw women spatial behavior based on two factors of "fear of crime", and "public place functionality" (Figure. 1).

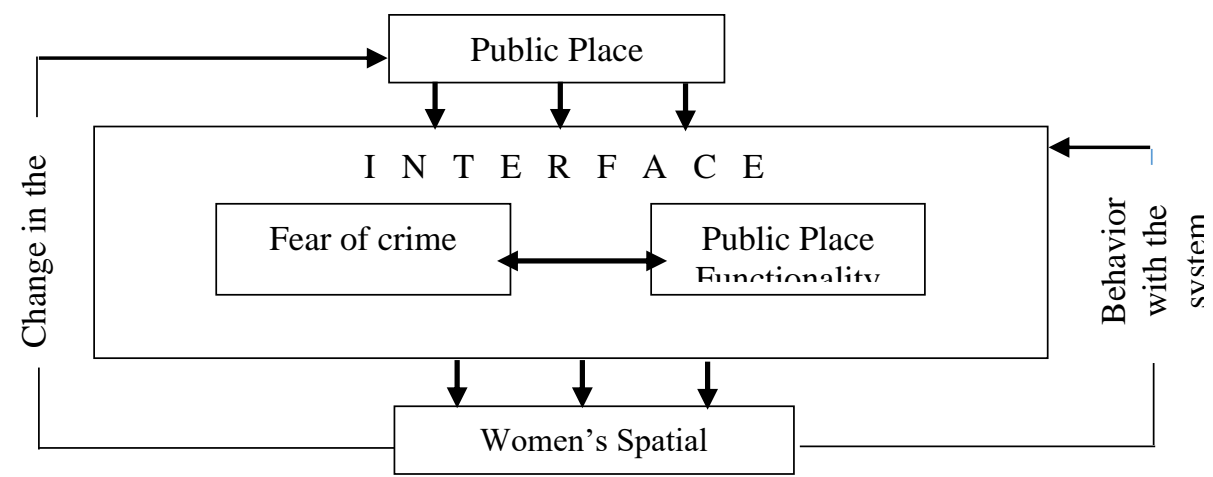

Figure 1. Women spatial behavior based on two factors of "fear of crime", and "public place functionality" 
The behavioral interface is in the frame, within which women shape the image of their world. Framework for investigating the behavioral patterns is based on each one of those relationships that manifest themselves as spatial movements and location decisions.

\subsection{Materials and methods}

The study applies combinational research methods with a qualitative and quantitative approach which include, analytical, descriptive, correlation and logical reasoning methods. The study also uses direct observations and questionnaire in fieldwork within the context of study and desk study. Accordingly, the study evaluates the spatial behaviors of women within the historical urban context of Kerman, which includes the Grand Bazaar as an urban public place. The study conducts the questionnaire data analysis, in order to measure 'Fear of Crime' and 'Public Space Functionality' factors; within the case study through which it is possible to evaluate men and women's spatial behavior.

\subsection{Data Collection and Field Study}

In the field study, 40 randomly men and women have participated voluntarily; in order to have equal analysis, 20 men and 20 women were selected. All of the participants were users of Grand Bazaar, and there was not any limitation for their age, race, and their occupations. As it was mentioned in the former section, this study utilizes the questionnaire data analysis in order to measure factors of fear of crime and functionality in public space. The survey conducts the questionnaire data analysis to measure the fear of crime in the physical environment of Grand Bazaar, which are anxiety towards the physical and social environment, and indirect places for crime victimization. As Valentine (1989), referred to some women's 'fear of crime' measures: avoidance and isolation which involved a sense of restriction in use and occupancy of a public place. Subsequently, some of the questionnaire items were as: (1) "Do you feel Bazaar, is a safe place for you", (2) "Have you ever faced the verbal or physical harassment in Bazaar", (3) "Are you more cautious while you are walking in Bazaar environment", (4) "Are you feel anxious in less crowded districts of Bazaar", and "I prefer to ignore the shops on dead-end paths of the Bazaar".

On the other side, the questionnaire tries to measures how Bazaar as a public place is successful to meet its user's social, commercial and recreational needs. In this way, some of the questionnaire items were as: (1) "I come to Bazaar just for shopping", (2) "I come Bazaar just for having a good time", (3) "Are you using cafes and restaurants in the Bazaar if you were alone", (4) "Are you using mosques inside the Bazaar", (5) "Is Bazaar one of your meeting place with your friends", (5) "Are you participating in community programs such as , periodical festivals, matches, exhibitions, and ceremonies inside the Bazaar", and "Are you spending any time in Bazaar for setting, reading, sun bathing, playing, or chatting with your friends".

This study uses 5 - point Likert scale (1. All the time, 2. Usually, 3. In average, 4. Rarely, 5. Almost never). Moreover, the study utilizes 'cross-tab analysis' in order to measure the mentioned factors in the questionnaire.

\section{The Case Study of Grand Bazaar}

Kerman is one of the Greatest cities in Iran, and it is located near the central desert of Iran. This city has a historical central core, which includes Grand Bazaar as one of its urban public places (Figure. 2). The Grand Bazaar has two main East-West and North-South Axis. The main entrance portal of the East-West axis is located in the Arg Square (figure. 3). The EastWest axis connects the Arg Square to the Moshtagh Square. 


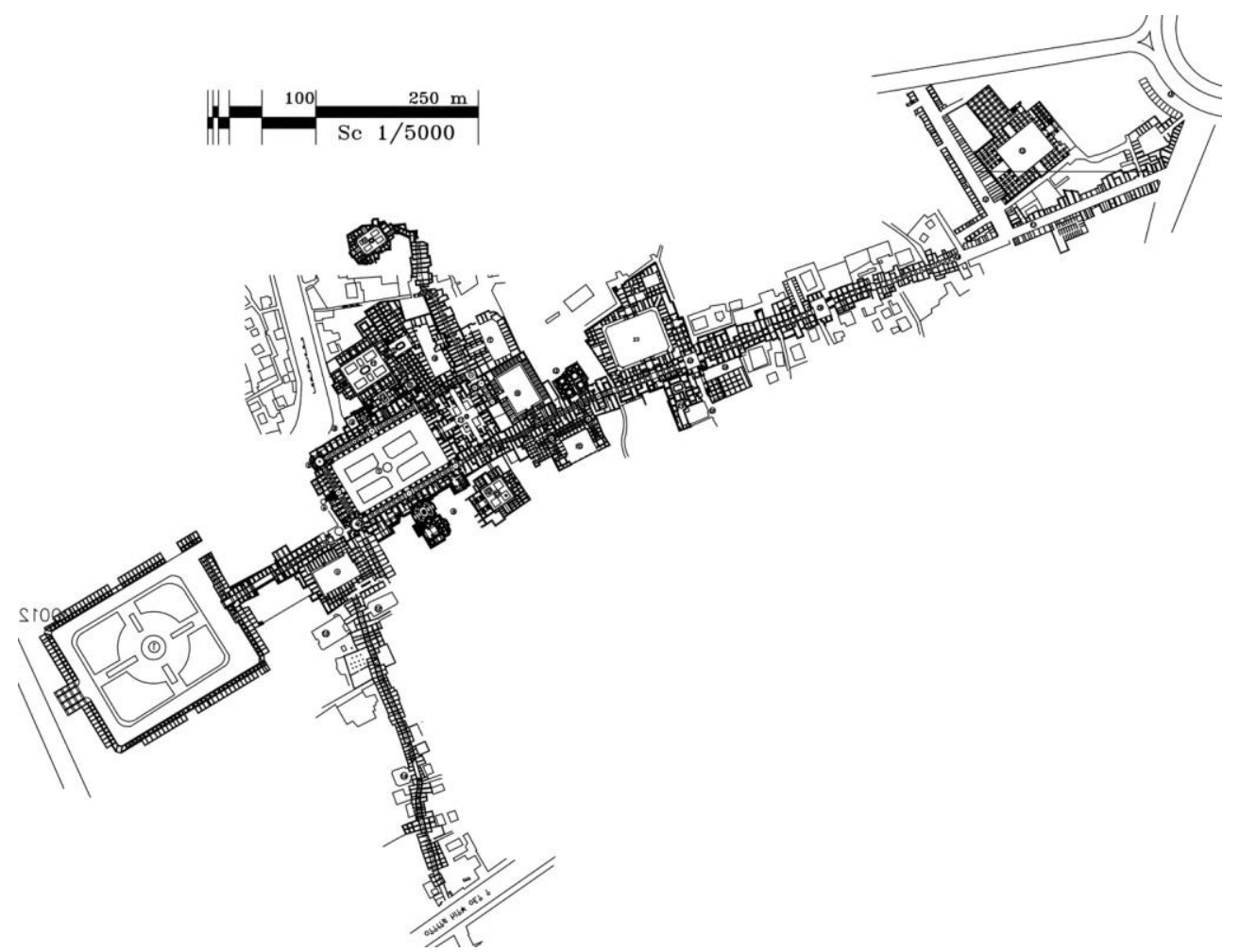

Figure 2. The map of the main of Grand Bazaar and its open public spaces

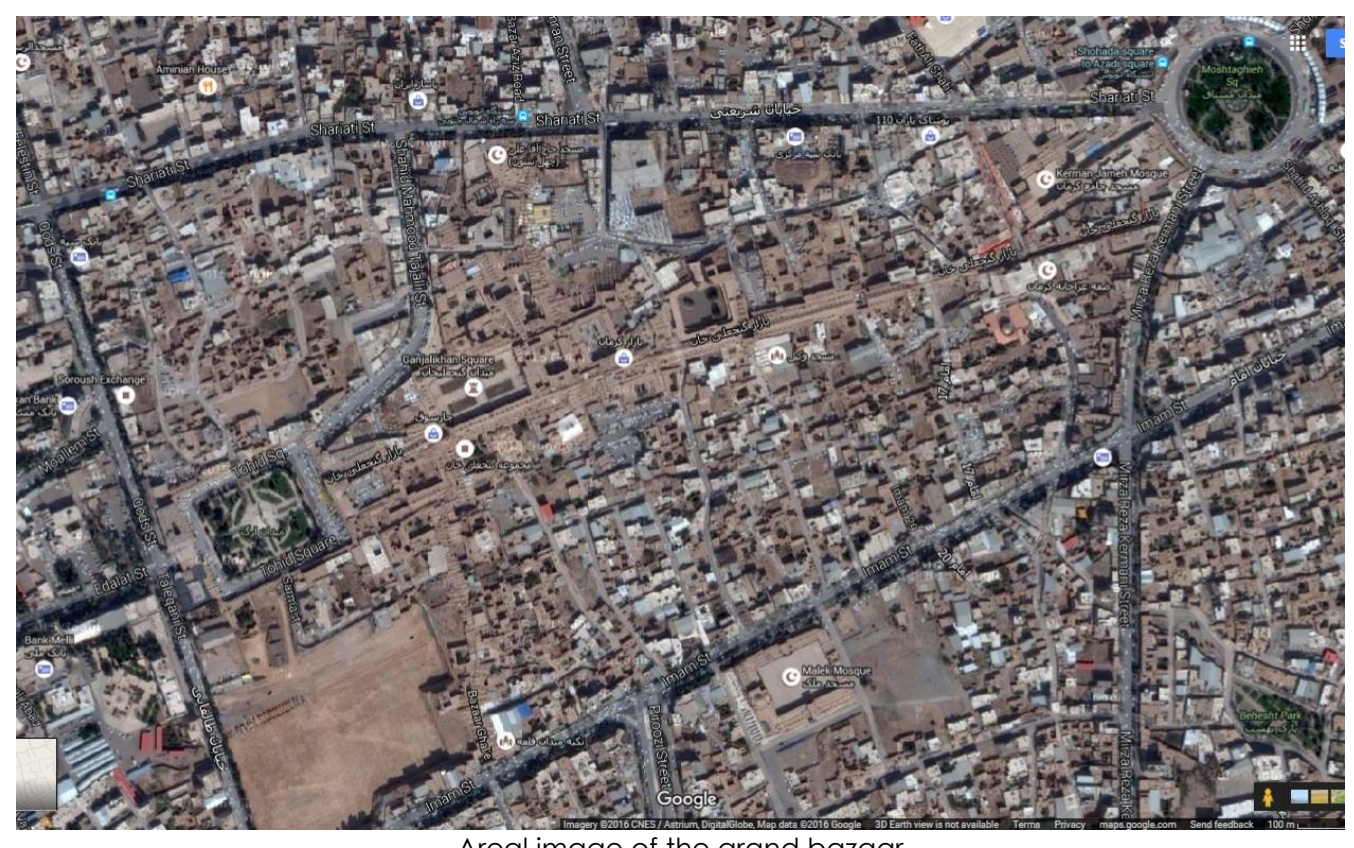

Areal image of the grand bazaar

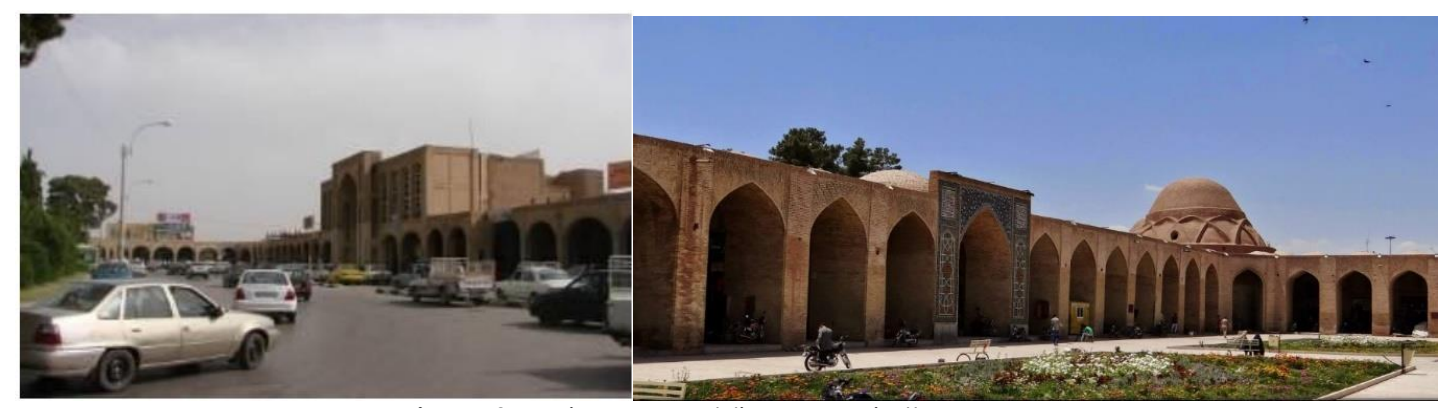

Figure 3. Main open public spaces in the Bazaar 
This Bazaar is considering the second biggest and longest Historical Bazaar in Iran after Tabriz's Bazaar. This complex in its design has all the required facilities, such as traditional Baths, traditional schools, mosques, public squares, and most importantly its commercial Axes (figures $4,5,6$ ). This complex is still active and crowded today and it is representing a welldefined public place in Kerman province.
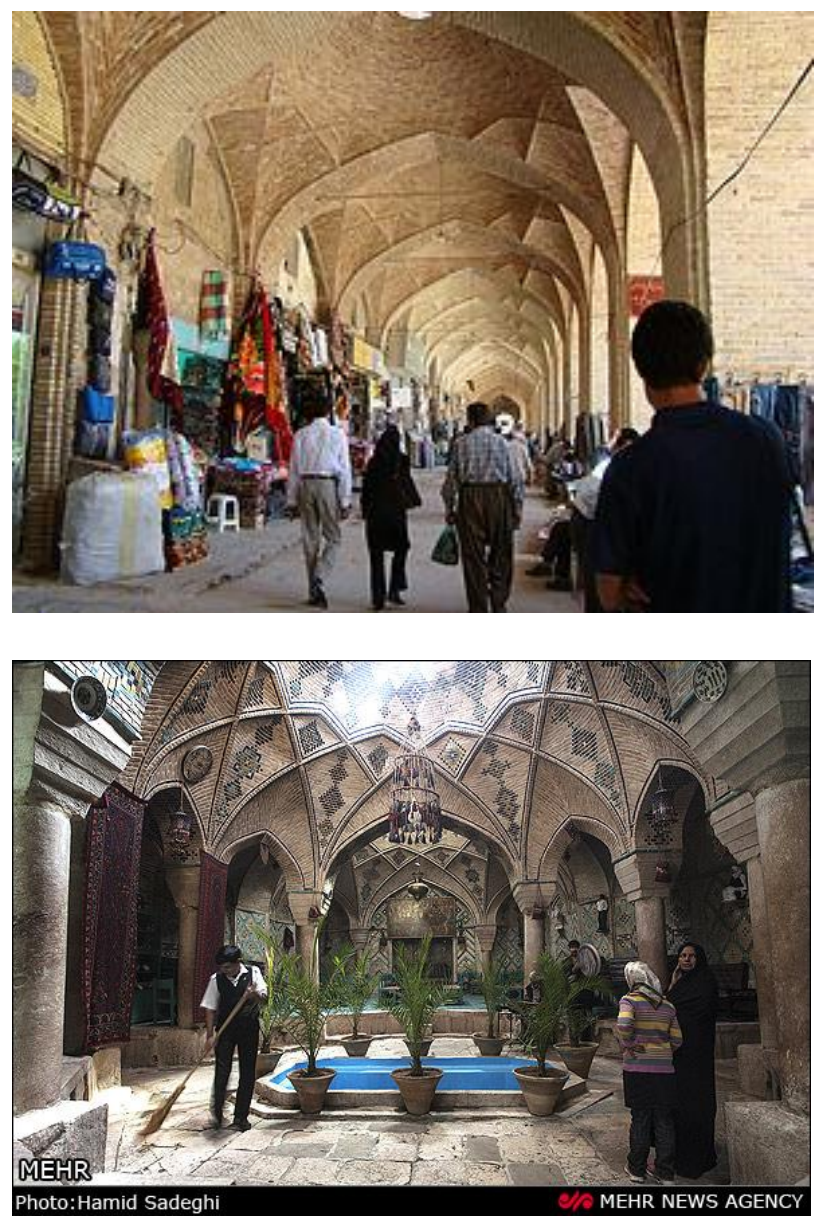

Figure 4-5. The main axis of Bazaar, including the shops and smaller sections
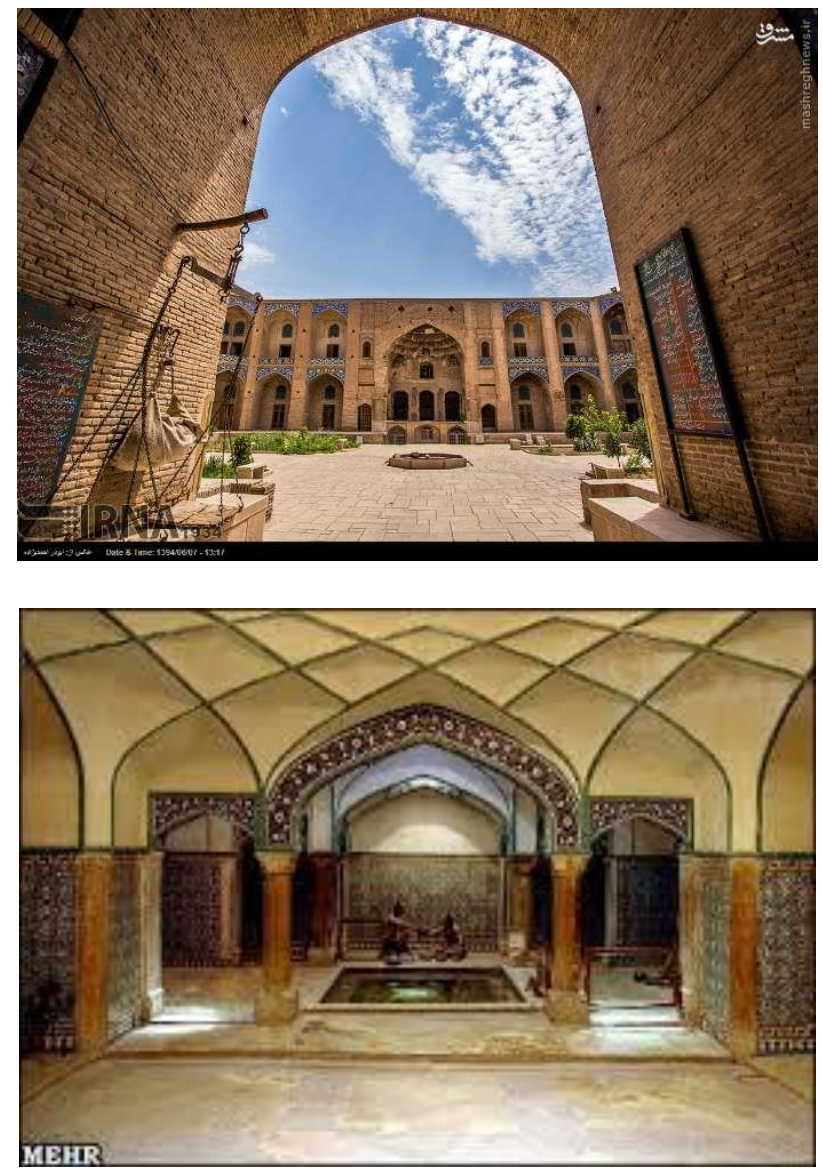

Figure 6-7. Public functions like the historic school and bath along the Bazar

Direct observation in Grand Bazaar indicates the strengths and weakness of the case study. Conducting direct observation in the field make it possible to extract the strength and weakness of Grand Bazaar as a historical public place; table 1 indicates the strength and weakness in terms of functional dimension, social, perceptual, and physical dimensions. 


\begin{tabular}{|c|c|c|}
\hline \multicolumn{2}{|r|}{ Strengths } & Weaknesses \\
\hline 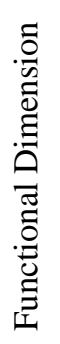 & $\begin{array}{l}\text { - } \\
\text { Mixed- used axis of the Grand Bazaar } \\
\text { Multifunctional facilities } \\
\text { monuments } \\
\text { Tourism attraction for its historical } \\
\text { Grand Bazaar }\end{array}$ & $\begin{array}{l}\text { Deterioration and lack of maintenance in some } \\
\text { neglected parts } \\
\text { - Some parts of the Bazaar are completely } \\
\text { abandoned }\end{array}$ \\
\hline 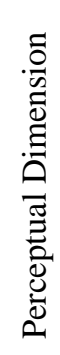 & $\begin{array}{l}\text { Presence of historical buildings } \\
\text { - } \quad \text { The Grand Bazaar, itself as a strong } \\
\text { path in the cognitive map of users. } \\
\text { - } \quad \text { Legibility, connection, and continuity } \\
\text { of signs in the Grand Bazaar }\end{array}$ & $\begin{array}{l}\text { - Fear of crime within the historical context } \\
\text { - Visual deterioration as a result of poor } \\
\text { maintenance in some parts of Bazaar } \\
\text { Lack of adequate lighting in some parts of Bazaar } \\
\text { during afternoon and night time }\end{array}$ \\
\hline 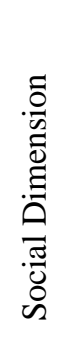 & $\begin{array}{l}\text { - } \\
\text { - } \\
\text { Active commercial axis } \\
\text { - } \\
\text { cafes in the Bazaar } \\
\text { - } \\
\text { to the relive tivious ceremonies within the Bazaar } \\
\text { - } \quad \text { Diversity of users }\end{array}$ & $\begin{array}{l}\text { - Immigration and newcomers in nearby } \\
\text { neighborhoods } \\
\text { - } \quad \text { Lack of people participation } \\
\text { - Lack of other social communities except for } \\
\text { religious one } \\
\text { - } \quad \text { Lack of inclusive spaces for children }\end{array}$ \\
\hline 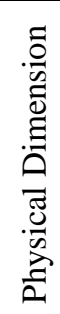 & $\begin{array}{ll}- & \text { Simple organic forms } \\
- & \text { Rhythmic and oriented axis } \\
\text { - } & \text { In closing two big public squares, and } \\
\text { several smaller open areas }\end{array}$ & $\begin{array}{l}\text { - Physical deterioration within historical buildings } \\
\text { and axis in Bazaar } \\
\text { - } \quad \text { Inadequate seating areas in its public squares and } \\
\text { other open spaces. } \\
\text { - } \quad \text { inadequate green areas in its public squares }\end{array}$ \\
\hline
\end{tabular}

Table 1. Strengths and weaknesses of functional, perceptual, Social, and physical dimensions 
Table 2. Spearman Correlation between Gender, time of Usage and Fear of crime

\begin{tabular}{|c|c|c|c|c|c|c|c|c|c|}
\hline & & a1 & A3 & A4 & A5 & A7 & A8 & A9 & A10 \\
\hline A1 & $\begin{array}{l}\text { Correlation Coefficient } \\
\text { Sig. (2-tailed) }\end{array}$ & 1.000 & $\begin{array}{r}-.098 \\
.435\end{array}$ & $\begin{array}{r}.366^{* *} \\
.003\end{array}$ & $\begin{array}{r}.458^{* *} \\
.000\end{array}$ & $\begin{array}{l}.210 \\
.094\end{array}$ & $\begin{array}{r}.540^{* * *} \\
.000\end{array}$ & $\begin{array}{l}.196 \\
.117\end{array}$ & $\begin{array}{r}-.244 \\
.050\end{array}$ \\
\hline A3 & $\begin{array}{l}\text { Correlation Coefficient } \\
\text { Sig. (2-tailed)q }\end{array}$ & & 1.000 & $\begin{array}{r}-.243^{*} \\
.047\end{array}$ & $\begin{array}{l}.120 \\
.334\end{array}$ & $\begin{array}{l}.142 \\
.256\end{array}$ & $\begin{array}{l}.069 \\
.583\end{array}$ & $\begin{array}{l}.119 \\
.340\end{array}$ & $\begin{array}{r}-.027 \\
.829\end{array}$ \\
\hline
\end{tabular}

**. Correlation is significant at the 0.01 level (2-tailed).

*. Correlation is significant at the 0.05 level (2-tailed).
A1- Gender
A3- Time of usage (ranges from early morning to late afternoon)
A4- Do you feel Bazaar, is a safe place for you
A5- Have you ever faced the verbal or physical harassment in Bazaar
A7- Are you more cautious while you are walking in Bazaar environment
A8- Are you feel anxious in less crowded districts of Bazaar
A9- I prefer to ignore the shops on dead-end paths of the Bazaar
A10- Do use the mosques in the Grand Bazaar

\section{Results and Discussion}

As it was mentioned, the study uses 5 - point Likert scale for questionnaire data analysis; therefore, in this study in order to analyses the Likert scale type data, Spearman correlation coefficient was conducted. Table 1 shows the existing relationship among the data. First raw (A1) expresses the correlation between Genders as the main goal of this study. The other row (A3) is showing the general relations between the time of using the space and other variables.

Due to the goal of this research, the data entry was conducted by giving the value 1 to female, and 0 to male participants. Accordingly, any positive correlation in the first row shows the women's agreement with the statement. And any negative correlation in the first row shows a stronger disagreement in female participant in comparison with male participant replies. Thus, if the correlation is closer to 0 , it shows that the answers are very similar between male and female participates (there is no significant relationship between the given Question and gender).

In the first section of the analysis which is presented in Table 2, shows the correlations between the 'fear of crime' according to gender (Al row).

The data shows a significant discrimination of female users as they report more feeling unsafe in compare with male users $\left(\mathrm{A} 1^{*} \mathrm{~A} 4\right)$. Also, there is a strong correlation between gender and verbal and physical harassment according to this study $\left(\mathrm{A} 1^{*} \mathrm{~A} 5\right)$, female users have reported being faced with such behavior repeatedly; as a consequence, this fear will cause their avoidance to use and participate in Bazaar as an urban public place. The female participants also feel more anxious in the less crowded axis of the grand bazaar $\left(A 1^{*} A 8\right)$; which can be another reason for them to feel uncomfortable and terrified in a public place. The A3 row shows how the time of usage affects the other variables. Interestingly, the data shows all participants feel more vulnerable as night approaches regardless of their gender.

In the second section of the analysis which is presented in Table 3, shows the Spearman Correlation between -Gender, time of Usageand Public Place Functionality. 
Table 3. Spearman Correlation between -Gender, time of Usage- and Public Place Functionality

\begin{tabular}{|c|c|c|c|c|c|c|c|c|c|}
\hline & & a1 & A3 & B1 & B2 & B3 & B4 & B5 & B6 \\
\hline a1 & $\begin{array}{l}\text { Correlation Coefficient } \\
\text { Sig. (2-tailed) }\end{array}$ & 1.000 & $\begin{array}{r}-.098 \\
.435\end{array}$ & $\begin{array}{r}.262 \\
.037\end{array}$ & $\begin{array}{r}-.282^{*} \\
.023\end{array}$ & $\begin{array}{r}-.081 \\
.523\end{array}$ & $\begin{array}{r}-.160 \\
.204\end{array}$ & $\begin{array}{r}-.050 \\
.695\end{array}$ & $\begin{array}{r}-.380^{* *} \\
.002\end{array}$ \\
\hline$\overline{\mathrm{A} 3}$ & $\begin{array}{l}\text { Correlation Coefficient } \\
\text { Sig. (2-tailed) } \\
\mathrm{N}\end{array}$ & & $\begin{array}{r}1.000 \\
67\end{array}$ & $\begin{array}{r}-.044 \\
.729 \\
65\end{array}$ & $\begin{array}{r}-.110 \\
.378 \\
66\end{array}$ & $\begin{array}{r}-.203 \\
.102 \\
66\end{array}$ & $\begin{array}{r}-.190 \\
.128 \\
66\end{array}$ & $\begin{array}{r}.011 \\
.927 \\
66\end{array}$ & $\begin{array}{r}-.295^{*} \\
.016 \\
66\end{array}$ \\
\hline
\end{tabular}

**. Correlation is significant at the 0.01 level (2-tailed).

*. Correlation is significant at the 0.05 level (2-tailed).

\section{A1- Gender}

A3- Time of usage (ranges from early morning to late afternoon)

B1-I come to Bazaar just for shopping

B2-I come to Bazaar just for having a good time

B3- Are you using cafes and restaurants in the bazaar

B4-Is Bazaar one of your meeting place with your friends"

B5-Are you participating in community programs such as periodical festivals, matches, exhibitions, and ceremonies inside the Bazaar

B6- Are you spending any time in Bazaar for setting, reading, sunbathing, playing, or chatting with your friends

The result shows that women do not identify the grand bazaar as a place for public leisure activities $\left(A 1^{*} B 2\right.$ \& $\left.A 1^{*} B 6\right)$. It seems that the place feels more relative to male usage. The analysis shows no gender-related differences in using the space as a place for community, meetings, using cafes and restaurants, attending religious ceremonies, and public exhibitions, therefore, it seems that both men and women use the Bazaar in those aspects similarly. As it was mentioned in the literature review women usually use public spaces as a place for their daily outdoor activities such as shopping, the analysis shows similar results, it shows that they put less time for leisure activities and more for the functional approach of shopping. In case of time, the analysis shows that people use the space as a place for setting, reading, sunbathing, playing, or chatting with their friends in the morning, and as the night approaches people start to evacuate the place.

\section{Conclusion}

The overall analysis in the case study of Grand Bazaar as a public place indicates that in most parts, there is an apparent discrepancy between two genders of male and female's environmental perception and public place usages. The study shows women's fear of crime puts significant effects on their spatial behavior in public place, this issue makes them avoid and restrict their movements within Bazaar public places at specific times during the day. It should be noted that Islamic local culture of the environment also affects the self-identity of women as they are not feeling quite comfortable to reveal their expressions, feelings, and their bodily movement in urban open public places.

The other part of analysis 'public place functionality' provides an explanation for differences between two types of usage in Grand Bazaar. Women mostly as it was discussed in literature review devote their times in public spaces to provide their house or their children's requirements, and they spent less time in public spaces for individual purposes such as chatting with their friends, seating, reading or participating in any leisure activities. However, men as analysis suggest, use the Grand Bazaar facilities more for recreational activities compared to the women's activates in this place.

Throughout the analysis, it is possible to extract patterns of spatial behavior which actually has a significant effect on women's lives formation. Therefore, this research concludes that any proposing public place design alternatives, should see women's needs in that context and decoding hidden socio-cultural parameters which makes them behave in certain patterns in urban public spaces. Meanwhile, awareness about the importance of women's usage and activities in public spaces should become the priority of urban designers and urban planners because women make up $50 \%$ of the population in each society; and good public space should be supportive and democratic to all its users.

\section{Acknowledgements}

This research did not receive any specific grant from funding agencies in the public, commercial, or not-forprofit sectors. 


\section{Conflict of interests}

The author declares no conflict of interest.

\section{References}

Altman, I., \& Zube, E. H. (2012). Public places and spaces (Vol. 10): Springer Science \& Business Media. https://www.springer.com/gp/book/9781468 $\underline{456035}$

Ardener, S. (1981). Women and space: Ground rules and social maps: Berg Publishers. https://books.google.com.cy/books?id=60OAAAAIAAJ

Brooks, J. (1974). The fear of crime in the United States. Crime \& Delinquency, 20(3), 241-244. doi:https://doi.org/10.1177/001112877402000 303

Carr, S., Francis, M., Rivlin, L., \& Stone, A. (1992). Public Space (S. Carr Ed. illustrated, reprint ed.): Cambridge University Press. https://books.google.com.cy/books?isbn=05 21359600

Day, K. (1995). Assault prevention as social control: Women and sexual assault prevention on urban college campuses. Journal of Environmental Psychology, 15(4), 261-281. doi:https://doi.org/10.1006/jevp.1995.0024

Dovey, K. (1985). An ecology of place and placemaking: Structure, processes. Paper presented at the Place and Placemaking: proceedings of the PAPER 85 Conference, Melbourne,

Australia. http://www.citeulike.org/user/eye lean/artic le/6336547

Fenster, T. (1999). Space for gender: cultural roles of the forbidden and the permitted. Environment and Planning D: Society and Space, $\quad 17(2)$, 227-246. doi:https://doi.org/10.1068/d170227

Franck, K. A. (2003). Women and Environment. In R. B. Bechtel \& A. Churchman (Eds.), Hand Book of Environmental Psychology (pp. 347367): John Wiley \& Sons. https://www.springer.com/gp/book/9780306 446801

Franck, K. A., \& Paxson, L. (1989). Women and urban public space Public places and spaces (pp. 121-146): Springer. https://doi.org/10.1007/978-1-4684-5601-1_6

Golledge, R. G. (1997). Spatial behavior: A geographic perspective: Guilford Press. https://books.google.com.cy/books?isbn=15 $\underline{72300507}$

Hartsock, N. C. (1983). The feminist standpoint: Developing the ground for a specifically feminist historical materialism Discovering reality (pp. 283-310): Springer. https://books.google.com.cy/books?isbn=04 15945011

Henley, N. (1977). Body politics: Power, sex, and nonverbal communication: Prentice Hall. https://books.google.com.cy/books?id=u6xAAAAMAAJ

Lang, J. (2017). Urban design: A typology of procedures and products: Routledge. https://books.google.com.cy/books? isbn=13 17282914

Leavitt, J. (1988). Creating Architectural Theory: The Role of Behavioral Sciences in Environmental Design. Retrieved from https://www.jstor.org/stable/43028893

Michelson, W. M. (1985). From sun to sun: Daily obligations and community structure in the lives of employed women and their families: Government Institutes. https://books.google.com.cy/books?isbn=08 65981493

Moser, C. (1987). Women, human settlements, and housing: a conceptual framework for analysis and policy-making. London; New York Tavistock Publications. doi:http://www.pastwomen.net/fr/bibliografi a/women-human-settlements-and-housinga-conceptual-framework-for-analysis-andpolicy-making

Riger, S., \& Gordon, M. T. (1981). The fear of rape: A study in social control. Journal of Social Issues, 37(4), 71-92. doi:https://doi.org/10.1111/j.15404560.1981.tb01071.x

Saegert, S., \& Hart, R. (1978). The development of environmental competence in girls and boys. Play: An anthropological perspective, 157-176.

https://www.bispsurf.de/Record/PU198004011247/RIS

Valentine, G. (1989). The geography of women's fear. Area, 385-390. doi: https://www.jstor.org/stable/20000063

Wilson, E. (1992). The sphinx in the city: Urban life, the control of disorder, and women: Univ of California

Press. https://books.google.com.cy/books?isbn=05 20078640

Young, I. M. (1990). Throwing like a girl and other essays in feminist philosophy and social theory.

https://books.google.com.cy/books?id=6Sw -AAAAMAAJ 